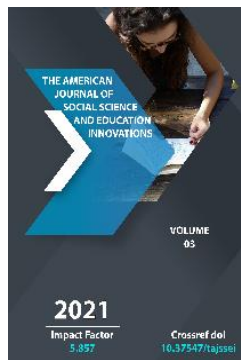

\title{
The Influence Of The Globalization Process On The Spiritual Culture Of The Personality
}

\author{
Jonbek Boysunov \\ Lecturer, Karshi State University, Uzbekistan
}

Journal Website:

http://usajournalshub.c om/index,php/tajssei

Copyright: Original content from this work may be used under the terms of the creative commons attributes 4.0 licence.

\section{ABSTRACT}

The article is devoted to the study of the process of the influence of globalization on the spiritual culture of the individual. The influence of globalization on the life of a person and society, influencing factors and its results are analyzed. The problem of changes occurring in the spiritual appearance of an individual, its causes and consequences were studied on the basis of objectivity and led to scientific conclusions. The fact that globalization today is the main tendency of modern society and has a contradictory impact on the spiritual culture of an individual, suggests that the issue under study is extremely relevant and significant.

\section{KEYWORDS}

Influence, globalization, spiritual appearance of a person, individual

\section{INTRODUCTION}

Currently, humanity lives in an extremely stressful and difficult time, which is changing rapidly, radically different from the times that have survived so far. Having reached the XXI century, there is not a single sphere left that would not be affected by globalization. Initially, globalization was reflected in the economic development of states, but by now it 
covers all processes, from politics, morality, national and spiritual life to the daily life of people.

From this point of view, globalization has a contradictory impact on the formation and change of the spiritual image of the individual. Keeping in mind the huge contribution of globalization to the development of modern society, one of the most important tasks is to reduce the negative consequences of globalization, to implement measures to eliminate it.

\section{METHODS AND LEVEL OF RESEACH}

In examinig this scientific topic, consistency, historicity, as well as methods of sociological, comparative and empirical analysis were used. The issues related to the concept of globalization, its features and impact on the life of an individual and society are discussed. This issue was considered in many works of scientists and philosophers, such as (D. McLean, scientist T. Levitt, V.S.Buyanov, E. Fromm, I. Karimov, K. Nazarov, A. Erkaev, E. Yusupov, S. Otamurodov).

\section{RESULTS OF THE RESEACH}

Globalization is one of the main trends that determines the specifics and features of the XXI century. Globalization has penetrated all spheres of society and has led to the emergence of a new order throughout the world. This phenomenon is interpreted as a specific current state of the socio-economic, political-legal, spiritual and cultural life of the peoples of the world, proceeding in their internal and external processes and their human development.

Scientists, philosophers and politicians take different approaches and express their attitude to this problem. Scientist and philosopher K. Nazarov emphasizes that "globalization is the global significance of the processes occurring as a result of the development of humanity and the world integration of the life of society" $[1,676]$. The rich spiritual and cultural heritage and potential created by each nation are important for the preservation of its national identity, selfdetermination, clarification of the strategy and directions of development. In addition, occurring in the world under the ideological and spiritual upheavals, a special place is occupied by its place in the world political and international arena, its influence on world civilization. The concept of globalization was first used in the early 80 s of the XX century as a factor that caused changes in the economic sphere. The term globalization in 1981-1983 was used in the articles and books of the American sociologist D. Maclin, the scientist T. Levitt, and the English scientist H. Robertson. [2,17-18]

In fact, globalization, since the beginning of the second half of the 2oth century, has been in various scales and manifestations, and by our time this process is greatly increasing. "In the last quarter of the XX - early XXI century, globalization has incredibly accelerated (intensified). Any product of progress can be used for two different purposes, namely for good and evil. The process of globalization is no exception. This especially affects the spiritual culture of the individual. Regardless of the degree of the problem, our task is to search for preventive measures and fight against it. Today, the most urgent issue is strengthening the spiritual foundations of the independence of our Motherland, preserving our national values, traditions and customs, deep penetration into the hearts and minds of the people, especially the young generation, sense 
of love for our people, for our native land, fidelity to independence. President of the Republic of Uzbekistan Sh.M. Mirziyoyev "We will resolutely and continue the state policy in relation to youth. We will not only continue, but also raise this policy to the high level that today requires time as our main priority. We mobilize all the strengths and capabilities of our state and society so that our youth, possessing independent thinking, high intellectual and spiritual potential, become happy people who are not inferior to their peers in any area" [4, 14]. The problems arising in the sphere of spiritual life in the modern difficult period of globalization are increasingly actualizing the issues of preserving and improving the spirituality of our people, especially preserving and protecting the soul and consciousness of the younger generation from the influence of various harmful ideas and ideologies. Of course, the processes of globalization are determined by the strengthening of integration and partnership ties between states and peoples, the creation of favorable conditions for the free movement of capital and goods, labor, the rapid spread of scientific achievements, the harmonization of spiritual values on a universal human basis, and the acquisition of a new quality of intercivilizational dialogue. That is, according to Islam Karimov, "globalization is, first of all, an unprecedented acceleration of the pace of life" [5-110]. By the beginning of the 20th century, interaction between the countries of the world had become so intense that we can say with complete confidence that there is not a single state that has completely isolated itself from this process. Even those countries that seek to stay away from international organizations, not wanting to become their members, do not remain completely aloof from this process. Globalization is such a process that countries that say they are staying on the sidelines may be more affected by it. Such involuntary exposure often leads to negative consequences.

The President of the Republic of Uzbekistan Sh.M. Mirziyoyev states:

"We will resolutely and not hesitate to continue the state policy towards youth. We will not only continue, but as our main priority, we will raise this policy to the high level that time requires today. We mobilize all the forces and capabilities of our state and society so that our young people, who think independently, have high intellectual and spiritual potential, grow and be happy, not yielding to their peers in any area" [4, 14]. The problems that arise in the modern and difficult period of globalization in the sphere of spiritual life are increasingly actualizing the issues of preserving and improving the spirituality of our people, especially protecting the soul and consciousness of the younger generation from the influence of various harmful ideas and ideologies. Undoubtedly, the processes of globalization are determined by the strengthening of integration and partnership ties between states and peoples, the creation of favorable conditions for the free movement of capital and goods, labor, the rapid spread of scientific achievements, the harmonization of spiritual values on a universal human basis and the acquisition of a new quality of intercivilizational dialogue. That is, according to Islam Karimov, "globalization is, first of all, an unprecedented acceleration of the pace of life" [5-110]. By the beginning of the 2oth century, interaction between world countries had become so intense that it can be said with complete confidence that there is not a single state that completely isolated itself from this process. Even those countries that seek to stay 
away from international organizations, not wanting to become their members, do not remain completely aloof from this process. Globalization is a process where countries that remain outside may be more affected by it. Such unintentional influence often leads to negative consequences. In the era of globalization, which has a complex political and social nature, as a result of intentional economic, social, geopolitical goals, there is an undermining of age-old values, national thinking and the way of life of nations, and their spirituality is under serious threat. In a period when inextricably linked with the information revolution, the harmonization of values and the integration of financial markets, there are various ideological, spiritual threats aimed at destabilizing the spiritual and moral world of people. Considering from the point of view of development, globalization cannot be ignored; it is a historical process of the development of society. But at present, one of the most important tasks facing humanity is to prevent the negative impact of globalization on certain layers and structures of society. It is noteworthy that along with the influence of the globalization process, both moral threats and the "onslaught" of various, other cultures are increasing.

There are three main types of these threats and they include:

The first type is ideological attacks, which include: undermining the idea of personality; deterioration of the worldview of the individual; includes functions such as changing the position of an individual (manipulation).

The second type is ideological threats, consisting in the deterioration of personality behavior; in the undermining of the moral relations of the individual and the violation of the behavior of the individual (moral degradation).

The third type is information attacks and cyberattacks, which include: disinformation for the person (fake-information); it consists of actions aimed at lagging in the knowledge of the individual and weakening the activity of the individual.

The impact that globalization has on different countries is also different. This is due to the fact what is the economic informational, spiritual potential and policy of world countries. In order to better understand the essence of the phenomenon, it is necessary to increase the spiritual culture of the individual, to reduce the negative influence and increase the positive influence of such processes occurring in the world and on each country. The threats to security in the process of globalization of the spiritual sphere include information attacks that contradict the stable social life of a person, aimed at its various spheres, actions and threats in various forms, aimed at falsifying information, spreading false information, hiding, changing information, alienating it from national traditions, values, moral norms, ethnocultural and national-historical roots. For example, globalization leads to the degradation of morality. The concept of deviant morality (deviatio - lat. "Deviation") is used in special literature regarding the deteriorating behavior of a person. A deviation in personality behavior is a form of behavior that does not correspond to generally accepted or officially established social norms. It arises under the influence of the spiritual crisis of the individual and becomes the cause of the emergence of difficult situations between the individual and the social environment. Weak spiritual and moral development and specific personality traits 
(variability, excitability, instability, emotional susceptibility, isolation, indecision, etc.) provoke the emergence of deviant behavior in children and adolescents. And the spiritual and moral perfection of the individual contributes to the way out of various conflict situations that arise in public life. Globalization has a contradictory impact on spiritual culture. Given that all policies, including those in the field of economic policy and spirituality, are successful only if they are scientifically justified, we must recognize that our scientists provide our politicians with sufficient support in these matters. The policy pursued by our country on the world stage, and in order for it to bring greater effect and success, requires a deeper study and analysis of the essence, directions, features of globalization. It is by analyzing this process that it is possible to create an opportunity for politicians to choose the right path and make decisions. All over the world, the preservation of national identity is recognized not only as a factor ensuring the survival of nations, but also, at the same time, as a regulator of the spiritual and moral image. Because, firstly, a person's preservation of his originality in the process of globalization is the criterion of all progress. Secondly, globalization is an objective historical phenomenon that runs continuously, however, nowadays, attempts are being made more and more often to artificialize it, that is, to use it as a means of achieving one's goals. The principles of the modern way of life, conditioned by specific traditions and information communications in the renewing conditions of life, lead to changes in the spiritual appearance of a person, in the way of thinking.

Thirdly, the accelerating processes of economic, political and cultural globalization - the borders between world countries are of increasing relative importance and determine the internationalization of national culture and the processes of spiritual behavior of people. Nations threatened by these consequences intensify the desire to preserve their national and spiritual identity.

Fourth, in the current era of the formation of a new world order, the protection of young people from various spiritual, cultural, ideological threats has become a world problem, which in its importance is not inferior to other global problems.

In this respect, the national identity acts as a "protective mechanism".

Fifth, a special place is occupied by the involvement and activity of members of society, especially young people, in the implementation of the national idea, which is important for the development of our country, and the tasks identified in the country's development strategy, on the basis of which it develops, and involvement requires a mature spiritual image.

Globalization is the strengthening of the economy, culture, spirituality of different countries, interaction and connections between people. There is no more effective and powerful means of protecting our national spirituality from negative influences and threats than a national idea. In this process, such an important function as the protection of national and spiritual identity is manifested. To accomplish this task, not only knowledge, but also faith and conviction must be formed in the minds of young people and the population. The analysis of the principles of the growing need for the development of the spiritual culture of an individual seems appropriate in conditions where the process of globalization 
encompasses the socio-economic, political, spiritual and cultural aspects of modern social development.

Indeed, this process is considered the most comprehensive and complex social phenomenon, which are the main factors in its development and implementation:

a) The formation of interethnic relations between different peoples and nations;

b) Tireless enrichment and raising to a new qualitative level of the spiritual culture of the individual;

c) Taking into account the interests and needs of the individual;

d) It is necessary to take into account the strong influence of national and religious values on the formation of the spirituality of the people.

Consequently, the activity of a person's participation in this process is associated with the level of his awareness of existing interests and needs, an increasing need for the development of spiritual culture. The sociopsychological maturity of a citizen is determined by his active participation in state and public life. As the English philosopher of modern times Thomas Hobbes noted, "To draw a conclusion about what a state is, it is permissible, first of all, to study the mores, interests and characters of people" $[6,252]$. At the same time, under the influence of the interests of each member of society, relations between a citizen-society-state are formed. After all, the political and legal culture of citizens is a determining factor in the development of the country in all its spheres.

In the report of the First President of the Republic of Uzbekistan I. Karimov at a joint meeting of the Senate and the legislative chambers of the Oliy Majlis of the Republic of
Uzbekistan on the "Concept of further deepening democratic reforms and the development of civil society in the country", it was noted that deepening democratic processes, increasing the political activity of the population, on this basis, political and legal culture, ensuring the rights and freedoms of citizens in the information sphere are an important condition for building the foundations of a democratic society in Uzbekistan [7]. It is known that in the traditions of our national spirituality, the priority is the issue of combining the main aspects of the spiritual culture of the individual - faith, science, responsibility and kindness. For certain historical reasons, European ethical science did not pay due attention to precisely this mutual proportionality. As a result, today in this region there are very serious problems in the field of spiritual and cultural morality. In our opinion, morality has two aspects, the first is the apparent (external) side, serving to maintain a moderate level of moderation in interpersonal relationships, which can change depending on the circumstances. The second is botvinic (internal), that is, the aspect with which the individual is connected by his spiritual culture, and this aspect will no longer depend on external conditions, but on the belief and beliefs of the individual. The apparent aspect of the morality of the individual is expressed in obedience, observance of moral norms existing in society. The ethical norms of society, however, essentially relate to the sphere of politics, not spirituality, and are aimed at ensuring general tranquility and a stable situation in society. In fact, they take the form of normative (unwritten) rules and constitute the superficial part of the ethics layer in politics. In our region, the spiritual foundations of a perfectly worked out morality of an individual, in turn, are built 
on the basis of the relationship between his spiritual culture and nature (behavior), where the issue of faith and beliefs takes the leading place. As a person's behavior improves under the influence of his spirituality (that is, his natural qualities turn from flaws into virtues), his morality gradually moves from evasive behavior (uneducated behavior that pushes a person to selfishness) to exemplary behavior (morality, which becomes beautiful as a result of spiritual perfection). The upbringing of desire, passion is the path of spiritual improvement, and morality is the path of becoming diligent. But spirituality is not only about nurturing desire and passion. Spirituality begins with faith, improves with science, through analytical faith passes to the spiritual education of a person (self-education) and, finally, through spiritual enlightenment, reaches spiritual perfection.

The meaning of the proverb "Morality is the core of spirituality" is that the degree of a person's spiritual perfection is most clearly manifested in his behavior. Based on their historical experience, European peoples in the social and cultural sphere, in accordance with the legacy left by their ancestors, created scientific models and measurements, formed descriptions and systems. Maybe we have no right to condemn them or find deficiencies in them. But, how impossible it is to say that Uzbek national thinking has been formed over the past 70 years, and today it is no longer appropriate to thoughtlessly use yesterday's artificial forms forced into our minds to conduct scientific reasoning in the spiritual and moral sphere. Thus, the power of the press should be used to a greater extent to form the spiritual culture of the individual in ensuring public welfare. Only then we will have another opportunity to equip our people with the knowledge of history, spiritual and cultural heritage, political and legal knowledge. In fact, the expansion of the influence of the media on the formation of the spiritual culture of the individual is becoming a need of the time. This is a long-term process.

Before the state and public organizations of Uzbekistan of the XXI century, there should be just one of these stable qualities. Currently, the number of mass media and various information and communication networks is steadily growing in our country. But until the public can satisfy its needs for information (political information), timely and sufficiently disseminate information about events in the country and in the world.

In our information time, the public's need for information is steadily growing. Various newspapers called "yellow press" and TV and radio channels are more inclined towards entertainment characteristics. News and information have the property of continuous renewal and enrichment.

In changing the public outlook, in the formation of new thinking in the life of society, or vice versa, the newspaper and television do not yet have the means capable of exerting a stronger influence.

The Internet has become an important link in today's information space.

Currently, the Internet can be used not only through a computer network, but also through space satellites, radio signal, cable TV, telephone and cellular communications. The Internet is becoming an integral part of people's lives. Human knowledge alone about the surrounding reality, about the rules of behavior will not be enough for his spiritual and moral upbringing. It is necessary to develop in 
him willpower, a sense of responsibility, to cultivate in him a love of the environment, work, profession, science, kindness to people, to achieve the hearts of great goals. This is achieved in different ways, by different means, above all a sincere (from the heart) and consistent approach to the upbringing of the younger generation and tireless searches.

"Our great ancestors, - writes I.A Karimov, - I consider it appropriate to remind that at one time a whole complex of moral criteria was developed about a perfect person, speaking in modern terms, the Eastern code of conduct" $[8,991]$.

As I.A Karimov noted, "Today humanity lives, constantly feeling the influence of ideological forces spreading from distant and close sources, different in meaning and content, which serve only the interests of certain states and political forces" $[9,86]$. This is why ideological test sites are even stronger today than nuclear test sites. Because their influence spreads through radio, television, newspapers, magazines, the Internet; in general, everyone penetrates through information networks, which can haunt people at home, on the street, or at work.

Weapons made at nuclear test sites destroy only a certain territory, but funds spreading from ideological test sites in the form of various information, works of art, toys, essential goods are aimed at mastering the soul and mind of humanity. For example, some books imported from abroad under the guise of "religious literature" are political in nature and may go the wrong way by relying on disinformation propaganda about jihad. Or films that promote ignorance, cruelty and violence are also one of the harmful effects that are sent from landfill.
At the same time, more and more new methods of psychological influence are used through the media. In particular, there are attempts to openly condemn certain features of national life, to humiliate or make it seem as if there were no historical events at all, so that our great scientists who made a huge contribution to world culture and science, had nothing to do with us.

Also, we should not lose sight of attempts to create tension between regional states and create a false image of Uzbekistan in the global environment.

\section{CONCLUSION}

Up to now, in the modern era, the struggle for the soul and mind of a person was extremely complex. It merges and harmonizes with the processes of geopolitics and globalization. Awareness of all this happening, as well as the formation of ideological immunity in each person remains an urgent task. Created over the centuries, the content and essence of the principles of humanism, national pride, a perfect person, moral senses, tolerance, social cooperation, on the basis of spiritual and educational work carried out in our country, is the education of the younger generation with independent thinking, broad outlook, high spirituality.

\section{REFERENCES}

1. K. Nazarov. Fundamentals of Philosophy.-T .: Publishing House of the National Society of Philosophers of Uzbekistan, 2012.676-p.

2. V.S. Buyanova The essence of globalization. // / Globalization: Textbook$M$.: Publishing house of the RAG, S -2008. pp. 17-18. 
3. A. Lyubovtsev. "Spirituality" T., Publishing house "Spirituality"., 2018, 245-p.

4. Sh. M. Mirziyoyev. Together we will build a free and prosperous, democratic state of Uzbekistan.-T., Uzbekistan: NRU HSE, 2016. p. 14.

5. I.A. Karimov High spirituality is an invincible force. -T .: Spirituality, 2016. 110-p.

6. Scenes of reality: 96 classical philosophers (destinies; proverbs; aphorisms). $-\mathrm{T}$.: Generation of the new century. 2002, 252p.

7. I.A. Karimov "Concept of further deepening democratic reforms and development of civil society in our country." Report of the Legislative Chamber and the Senate of the Oliy Majlis of the Republic of Uzbekistan at a joint meeting. Tashkent, November 12, 2010.

8. IA Karimov High spirituality-invincible force-Tashkent, spirituality, 2008. 991-p.

9. I.A. Karimov Ideology of national independence - people's faith and faith in a great future. -T .: "Uzbekistan", 2000. 86 p.

10. Q.Nazarov. Fundamentals of Philosophy.-T : Publishing House of the National Society of Philosophers of Uzbekistan, 2012.676-p.

11. Buyaanov $V$.S. Sushchnost 'globalzatsii.//Globalzatsii: Uchebnik-M .: Izd-vo RAG, S-2008. 17-18-b.

12. A. Erkayev. Manaviyatshunoslik T., Manaviyat Publishing House, 2018, p.245.

13. Mirziyoyev Sh.M. Together we will build a free and prosperous, democratic state of Uzbekistan.-T., Uzbekistan: NMIU, 2016. p.

14. Karimov I.A. High spirituality is an invincible force. - T .: Manaviyat, 2016. 110-p.

15. Scenes of Truth: 96 Classical Philosophers (Fates; Wisdoms; Aphorisms). - T .: New generation. 2002, 252-b.

16. Karimov I.A. "The concept of further deepening democratic reforms and development of civil society in our country." Report of the joint session of the Legislative Chamber and the seat of the Oliy Majlis of the Republic of Uzbekistan. Tashkent, November 12, 2010.

17. Karimov I.A. High spirituality is an invincible force - Tashkent, Mahnaviyat, 2008. 991-p

18. Karimov I.A. The ideology of national independence is the belief of the people and confidence in the great future. $-\mathrm{T}$.: «Uzbekistan», 2000. 86-p

19. Nematov, O. THE PILGRIMAGE OF KHAZRAT ZAYNULOBIDIN. Zbiór artykułów naukowych recenzowanych., 83. 